\title{
PERBEDAAN BAHAN ATRAKTOR TERHADAP HASIL TANGKAPAN IKAN PELAGIS DENGAN MENGGUNAKAN PAYANG BUGIS DI PERAIRAN PASAURAN, PROVINSI BANTEN
}

\author{
(The Effect of Attractor Material on Pelagic Fish Captured Using Payang Bugis \\ in Pasauran Waters, Province of Banten)
}

\author{
Roza Yusfiandayani ${ }^{12}$ \\ Fakultas Perikanan dan Ilmu Kelautan, Institut Pertanian Bogor. \\ E-mail: ocha_roza@yahoo.com
}

\begin{abstract}
Rumpon (Fish Aggregating Device) as an auxiliary gear operated in Pasauran waters, Sunda strait was longer and more widely used in Indonesia to catch pelagic fish. The characteristic species composition, size and Gonado Somato Index (GSI) pelagic fish around 3 kinds of rumpon attractor materials, i.e. Cocos nucifera, Nypa fructican and A reca catechu leaves will determine the effects of attractor materials will endanger the sustainability of pelagic fish associated. Identification and composition length, weight and GSI pelagic fish were identified in this research with different attractor material in all seasons. Experimental fishing carried out by using payang Bugis. The result show that the Cocos nucifera leaves are the best attractor material based on the number of fish species and durability in all seasons. Further, the GSI of small pelagic fish were caught around rumpon are GSI I $4 \%$, GSI II 33\%, GSI III $35 \%$, GSI IV $25 \%$ and GSI V $3 \%$. Pelagic fish around attractor materials have GSI I-III 72\%. This result indicated that the small pelagic fish caught around rumpon are 'immature fish".
\end{abstract}

Keywords : fish aggregating device, attractor materials, fishing season

\begin{abstract}
ABSTRAK
Rumpon laut dangkal sebagai alat bantu dalam penangkapan ikan di perairan sekitar Pasauran, Selat Sunda telah lama dan semakin banyak digunakan di Indonesia untuk menangkap ikan pelagis. Karakteristik komposisi jenis, ukuran dan Tingkat Kematangan Gonad (TKG) ikan pelagis yang tertangkap di sekitar rumpon dengan menggunakan tiga bahan atraktor yang berbeda yaitu daun kelapa (Cocos nucifera), daun pinang (Nypa fructican) dan daun nipah (Areca catechu) akan menentukan apakah pengaruh bahan atraktor yang digunakan akan membahayakan kelestarian ikan pelagis yang berasosiasi. Identifikasi dan komposisi panjang, berat dan TKG ikan pelagis dilakukan dengan menggunakan bahan atraktor yang berbeda pada setiap musim dalam penelitian ini. Experimental fishing dilakukan dengan menggunakan alat tangkap payang Bugis. Hasil pengamatan menunjukkan bahwa atraktor daun kelapa merupakan bahan atraktor yang terbaik yang dapat digunakan sebagai atraktor pada rumpon dilihat dari hasil tangkapan serta daya tahan di suatu perairan pada setiap musim. TKG ikan pelagis kecil yang tertangkap di sekitar rumpon memiliki TKG I 4\%, TKG II 33\%, TKG III 35\%, TKG IV 25\% dan TKG V 3\%. Ikan hasil tangkapan di sekitar rumpon dengan bahan atraktor yang berbeda memiliki TKG I-III sebesar $72 \%$ sehingga dapat dipastikan bahwa ikan-ikan yang berkumpul dan tertangkap di sekitar rumpon adalah ikan yang belum memijah atau belum dewasa, sehingga ikan tersebut tidak sempat melakukan reproduksi.
\end{abstract}

Kata kunci: rumpon, bahan attraktor, musim penangkapan

\section{PENDAHULUAN}

\subsection{Latar Belakang}

Sumberdaya ikan mempunyai sifat yang dapat pulih kembali (renewable) namun kemampuan tersebut terbatas. Berdasarkan keadaan tersebut, maka pemanfaatan sumberdaya ikan harus diatur atau dikelola sebaik mungkin untuk mencapai pemanfaatan yang optimal dengan memperhatikan kelestarian sumberdaya ikan tersebut.

Keberadaan ikan pelagis sebagai komoditi perdagangan dari sektor perikanan di Indonesia merupakan salah satu sumberdaya yang menempati posisi besar, baik sebagai komoditi ekspor maupun sebagai komoditi yang dikonsumsi dalam negeri untuk memenuhi kebutuhan gizi nasional. Ikan pelagis dapat dikelompokkan menjadi dua yaitu ikan pelagis besar dan ikan pelagis kecil. Ikan pelagis besar diantaranya adalah ikan cakalang, tuna, tenggiri dan sebagainya. Ikan pelagis kecil adalah layang, kembung, selar, sunglir, terbang, lemuru, tembang, tanjau, siro, julungjulung, teri dan sebagainya.

Alat tangkap yang umum digunakan untuk menangkap ikan pelagis adalah jaring insang, jaring insang lingkar, payang, bagan, purse seine, troll line, pole and line, hand line dan sebagainya. Alat tangkap

\footnotetext{
${ }^{1}$ Corresponding author

${ }^{2}$ Staf Pengajar Departemen Pemanfatan Sumberdaya Perikanan, FPIK-IPB
} 
yang menggunakan alat bantu seperti rumpon sudah dilakukan pada perikanan purse seine dan lines yang sangat membantu meningkatkan hasil tangkapan ikan.

Perairan Selat Sunda merupakan salah satu dari sejumlah selat yang berada di perairan Nusantara dan memiliki kekayaan alam yang belum banyak dimanfaatkan untuk kesejahteraan dan peningkatan gizi masyarakat. Antisipasi perkembangan bahwa laut sebagai tumpuan hidup khususnya nelayan dan keluarganya, maka pengelolaan yang baik memungkinkan untuk melaksanakan pembangunan yang berkesinambungan.

Perubahan kondisi lingkungan perairan setiap musim memberikan pengaruh terhadap keberadaan sumberdaya ikan, karakteristik nelayan dan perubahan daerah penangkapan. Gambaran cuaca di lingkungan Selat Sunda dan Laut Jawa merupakan tipikal area yang dipengaruhi oleh gerakan angin pada periode muson barat dan muson timur. Fenomena ini dapat terlihat dengan adanya perubahan lingkungan yang dipengaruhi karakteristik Laut Jawa dan oseanik Samudera Hindia, terutama pada tiap-tiap puncak musim angin muson.

Usaha perikanan skala kecil pada umumnya melakukan kegiatan usaha penangkapan dengan jangkauan terbatas karena keterbatasan modal, sarana dan keterampilan yang dimiliki. Keterbatasan ruang gerak ini memberikan dampak pada rendahnya hasil tangkapan yang pada akhirnya menyebabkan rendahnya pendapatan mereka. Guna meningkatkan jangkauan daerah penangkapan diperlukan modal yang besar dimana hal ini justru yang tidak dimiliki oleh nelayan skala kecil. Salah satu alternatif yang dapat ditempuh untuk membatasi kendala tersebut adalah dengan menerapkan teknologi rumpon.

Penerapan teknologi rumpon akan memberikan kepastian mengenai daerah penangkapan dan hal ini diharapkan akan memberikan solusi bagi masalah yang dihadapi khususnya yang berkaitan dengan rancang bangun rumpon, bahan rumpon, jumlah dan jarak rumpon, produktivitas serta efisiensi penangkapan yang optimum.

Secara garis besar rumpon, baik rumpon laut dalam maupun rumpon laut dangkal terdiri dari empat komponen utama yaitu: (1) pelampung atau float; (2) tali atau rope; (3) pengumpul ikan atau atractor dan; (4) pemberat atau sinker.
Atraktor yang banyak digunakan berupa daun-daunan alami seperti daun kelapa, tyrewall, jaring dan kumpulan talitemali yang diikatkan pada bagian rakit telah berhasil meningkatkan efektivitas rumpon dalam memikat kelompok ikan. Nelayan tradisional memilih menggunakan daun-daun alami sebagai atraktor, hal ini dikarenakan jauh lebih murah dibandingkan dengan menggunakan atraktor buatan. Daun alami yang banyak digunakan sebagai atraktor adalah dari famili Cycadaceae seperti daun kelapa (Cocos nucifera), nipah (Nypa fructican), pinang (Areca Catechu) dan sebagainya.

Teori dan penelitian tentang berkumpulnya ikan di sekitar rumpon telah dilakukan sejak tahun 1967. Samples dan Sproul (1985) mengemukakan teori tertariknya ikan yang berada di sekitar rumpon disebabkan karena :

(1) Rumpon sebagai tempat berteduh (shading place) bagi beberapa jenis ikan tertentu;

(2) Rumpon sebagai tempat mencari makan (feeding ground) bagi ikan-ikan tertentu;

(3) Rumpon sebagai substrat untuk meletakkan telurnya bagi ikan-ikan tertentu;

(4) Rumpon sebagai tempat berlindung dari predator bagi ikan-ikan tertentu;

(5) Rumpon sebagai tempat sebagai titik acuan navigasi (meeting point) bagi ikanikan tertentu yang beruaya.

Belum diketahui apakah ikan yang berkumpul di sekitar atraktor yang berupa daun-daun alami disebabkan karena perbedaan bahan atraktor pada rumpon. Karakteristik jenis, ukuran dan kematangan gonad ikan-ikan pelagis yang tertangkap di sekitar rumpon akan menentukan apakah pengaruh bahan atraktor yang digunakan akan membahayakan kelestarian ikan pelagis yang berasosiasi. Data dasar ini akan digunakan untuk penyusunan pengembangan perikanan rumpon ditinjau dari tingkah laku ikan, jumlah rumpon dan produktivitas rumpon di suatu perairan yang dihubungkan dengan kelestarian sumberdaya ikan pelagis.

\subsection{Tujuan}

Penelitian ini bertujuan untuk :

(1) Mengetahui karakteristik jenis dan ukuran ikan-ikan pelagis yang tertangkap di sekitar rumpon dengan bahan atraktor yang berbeda.

(2) Mengetahui Tingkat Kematangan Gonad (TKG) ikan-ikan pelagis yang tertangkap 
di sekitar rumpon dengan bahan atraktor yang berbeda.

\section{BAHAN DAN METODE}

\subsection{Tempat dan Waktu Penelitian}

Penelitian dilaksanakan pada bulan Desember 2001 - September 2002 di perairan Pasauran, Selat Sunda (Gambar 1). Pembagian waktu penelitian berdasarkan: 1). Musim Peralihan 1 (MP1) bulan Maret 2002; 2). Musim Timur (MT) bulan Juni 2002; 3). Musim Peralihan 2 (MP2) bulan September 2002; dan 4). Musim Barat (MB) bulan Desember 2001.

\subsection{Bahan dan Alat}

Bahan-bahan yang digunakan dalam penelitian ini adalah :

(1) Rumpon

Selama penelitian digunakan 3 unit rumpon laut dangkal yang diletakkan pada kedalaman $45 \mathrm{~m}$ (Gambar 2). Masing-ma- sing rumpon memiliki komponen : (1). 3-6 batang bambu yang digunakan sebagai pelampung, panjang dan diameter bambu adalah 15 dan $0.1 \mathrm{~m}$; (2). daun kelapa, daun nipah dan daun pinang yang digunakan sebagai atraktor alami yang masing-masing berjumlah 25 pelepah; (3). tali atraktor dan tali jangkar adalah PE 18 $\mathrm{mm}$ dengan panjang $63 \mathrm{~m}$, tali pengikat atraktor alami yaitu $\mathrm{PE} 2-5 \mathrm{~mm}$ dengan panjang 30-50 cm; (4). pemberat yang terdiri dari dua buah batu yang masingmasing memiliki berat $50 \mathrm{~kg}$. Secara rinci deskripsi rumpon tersebut dapat dilihat pada Tabel 1.

(2) Atraktor

Daun kelapa (Cocos nucifera), daun nipah (Nypa fructican) dan daun pinang (Areca catechu). Contoh masing-masing daun yang diambil adalah 25 pelepah yang kemudian masing-masing pelepah daun tersebut dibelah menjadi dua dan diikat pada tali.

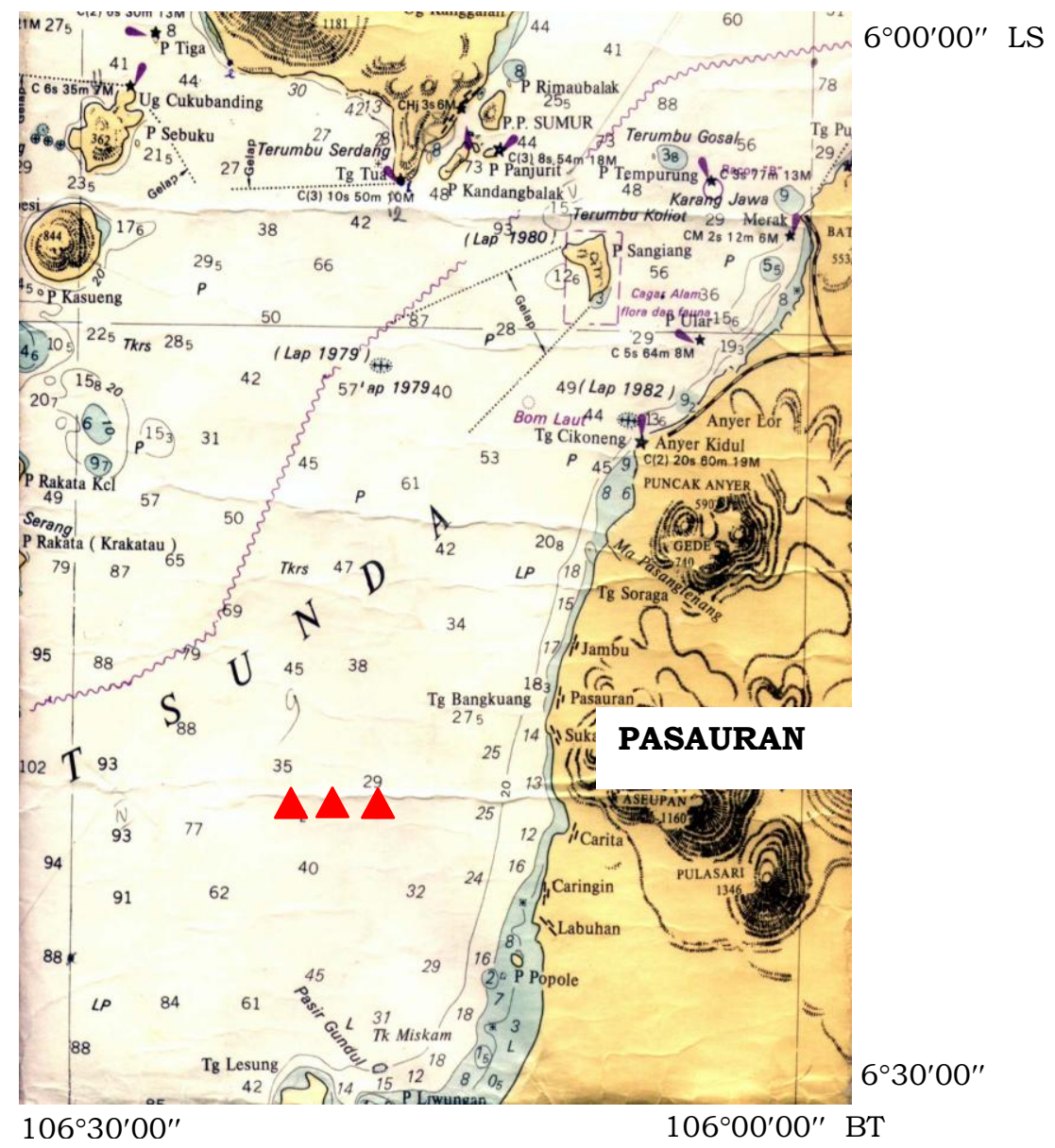

Gambar 1. Peta lokasi penelitian 
Tabel 1. Deskripsi rumpon yang digunakan pada penelitian

\begin{tabular}{|c|c|c|c|c|c|}
\hline No. & Komponen & Bahan & Ukuran & Jumlah & Berat \\
\hline \multirow[t]{2}{*}{1.} & Pelampung & & & & \\
\hline & - rakit Bambu & Bambu & $\begin{array}{l}\text { panjang }=15 \mathrm{~m} \\
\text { diameter }=0,1 \mathrm{~m}\end{array}$ & 3-6 batang & - \\
\hline \multirow[t]{2}{*}{2.} & Atraktor & & & & \\
\hline & - atraktor alami & $\begin{array}{l}\text { Daun } \\
\text { kelapa } \\
\text { daun nipah } \\
\text { daun } \\
\text { pinang } \\
\end{array}$ & - & $\begin{array}{l}25 \text { pelepah } \\
25 \text { pelepah } \\
25 \text { pelepah }\end{array}$ & - \\
\hline \multirow[t]{3}{*}{3.} & $\begin{array}{l}\text { Tali atraktor dan } \\
\text { jangkar }\end{array}$ & & & & \\
\hline & - tali & $\mathrm{PE}$ & $\begin{array}{l}\text { panjang }=63 \mathrm{~m} \\
(1.4 \times \text { kedalaman }) \\
\text { diameter }=18 \mathrm{~mm} \\
\end{array}$ & $45 \mathrm{~m}$ & - \\
\hline & $\begin{array}{l}\text { - tali pengikat } \\
\text { atraktor alami }\end{array}$ & $\mathrm{PE}$ & $\begin{array}{l}\text { panjang }=30-50 \mathrm{~cm} \\
\text { diameter }=2-5 \mathrm{~mm}\end{array}$ & $\begin{array}{l}1 \text { buah per } \\
\text { atraktor }\end{array}$ & - \\
\hline \multirow[t]{2}{*}{4.} & Pemberat & & & & \\
\hline & - pemberat & Batu & - & 2 buah & $100 \mathrm{~kg}$ \\
\hline
\end{tabular}

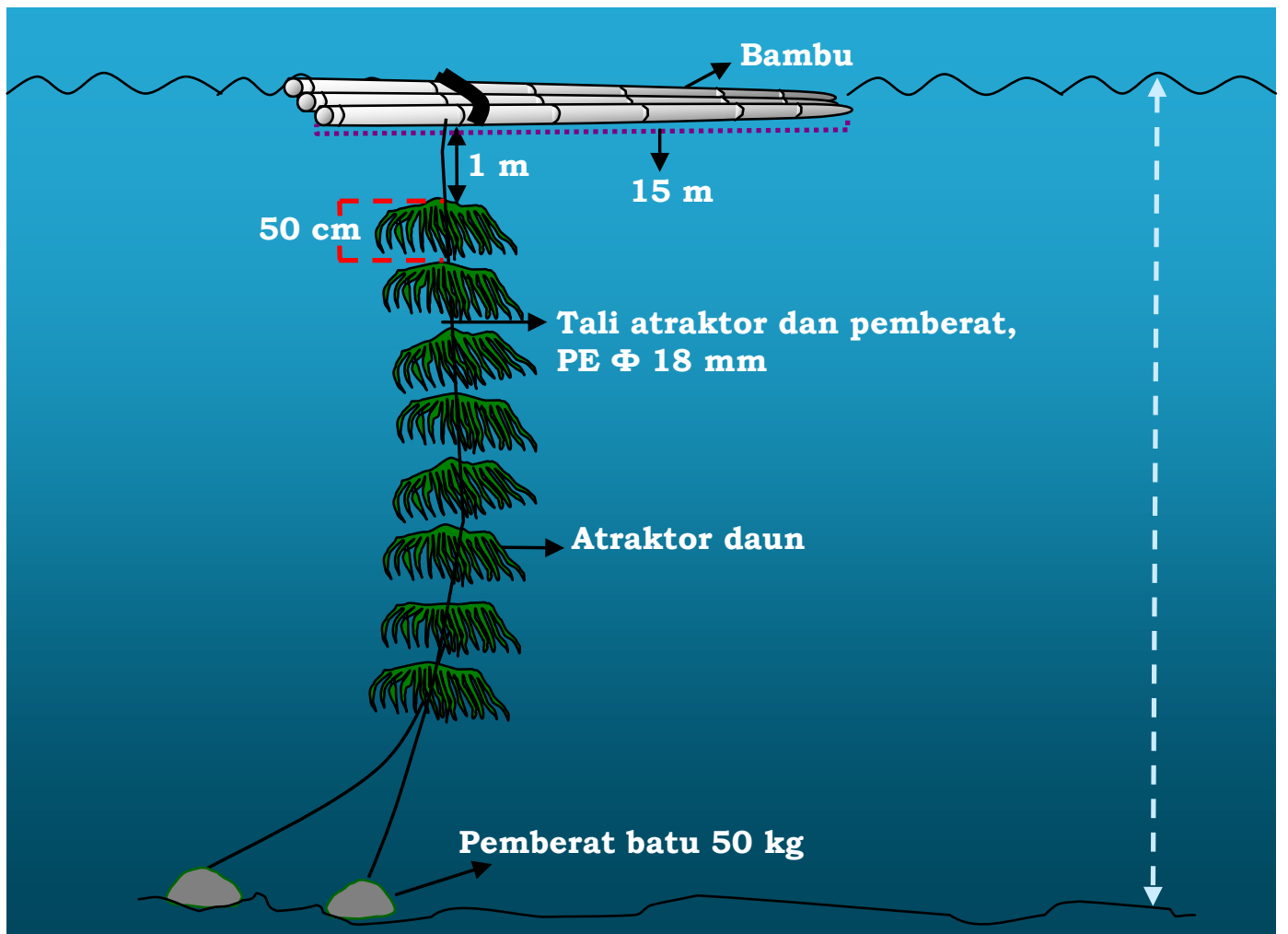

Gambar 2. Konstruksi Rumpon Laut Dangkal yang digunakan pada Penelitian

Alat-alat lain yang digunakan dalam penelitian ini adalah :

(1) secchi disc, refraktometer, termometer, Global Positioning System, sonar, seperangkat peralatan akustik portable, underwater camera, spektrofotometer ultraviolet, spektrofotometer Beckman, mikroskop binokuler, pipet, gelas obyek, gelas penutup, gunting, botol sampel, tisu, alat bedah, bahan pengawet (lugol
$40 \%$ dan formalin $4 \%$ ), bahan pengawet formalin acetat acid (faa), xylol, alkohol, parafin, alcian blue, kamera, timbangan, alat tulis menulis, buku identifikasi plankton dan perifiton (Yamaji, 1976) serta buku identifikasi ikan Fischer dan Whitehead (1974).

(2) Alat tangkap.

Untuk pengamatan sampel ikan dan evaluasi terhadap komposisi ikan di 
sekitar rumpon, digunakan alat tangkap sebagai sampling gear yang memungkinkan penarikan contoh yang mewakili populasi yaitu payang Bugis.

\subsection{Metode Penelitian}

Penelitian ini dilakukan dengan menggunakan metode Experimental Fishing dan metode survei. Metode experimenttal fishing dilakukan dengan mengikuti uji coba penangkapan pada rumpon laut dangkal di perairan Pasauran, Selat Sunda.

Uji coba penangkapan dilakukan pada masing-masing unit rumpon dengan menggunakan alat tangkap payang Bugis sebanyak lima kali ulangan. Survei sosial dilakukan dengan mengunakan kuesioner terhadap 20 orang nelayan dan 2 petugas pelelangan. Jumlah keseluruhan nelayan payang Bugis di Pasauran adalah 50 orang.

Data primer diperoleh dari hasil wawancara dengan para nelayan berdasarkan kuesioner yang dibuat dan juga diperoleh dari partisipasi aktif yakni ikut serta dalam operasi penangkapan. Data sekunder diperoleh dari kantor dinas perikanan setempat, TPI ataupun instansi lain yang terkait.

Pengambilan sampel ikan dilakukan dengan menggunakan metode Experimen-tal Fishing, yaitu berupa uji coba penangkapan. Kondisi perairan, jarak antara rumpon, kedalaman pemasangan rumpon dan kondisi oseanografi lainnya dianggap tetap berpengaruh pada penelitian ini.

Pengambilan sampel ikan dilakukan dengan melakukan penangkapan di sekitar rumpon dengan menggunakan alat tangkap payang Bugis. Penggunaan alat tangkap payang Bugis di lokasi penelitian tergantung pada kondisi oseanografi seperti angin yang kencang dan arus yang kuat. Pengambilan sampel ikan dilakukan setiap hari sejak rumpon tersebut dipasang pada pagi hari bersamaan dengan pengambilan plankton. Jumlah rumpon yang digunakan sebanyak 3 unit yang masing-masing unit rumpon dilakukan penangkapan ikan dengan payang Bugis. Dari setiap hasil tangkapan pada setiap tripnya, diukur bobot total hasil tangkapan dan dihitung jumlah total ikan pelagis hasil tangkapan. Anak contoh atau sub sampel diambil dari spesies ikan dominan hasil tangkapan payang Bugis dengan berbagai variasi ukuran dari yang terkecil sampai yang terbesar. Menurut Nasoetion dan Barizi
(1980), sebelum dianalisis lebih lanjut, data hasil tangkapan berdasarkan bahan atraktor dan musim yang berbeda diuji sebarannya terlebih dahulu untuk mengetahui apakah data yang diperoleh menyebar normal atau tidak. Uji kenormalan yang digunakan adalah "Uji Kenormalan Lilliefors". Setelah dilakukan "Uji Kenormalan Lilliefors" bila ternyata data yang diperoleh tidak menyebar secara normal, akan dilanjutkan dengan uji non-parametrik, yaitu "Uji Pangkat Bertanda Duncan (Duncan Signed Rank Test)". Data diolah dengan menggunakan program SPSS 10.0.

\section{HASIL DAN PEMBAHASAN}

\subsection{Payang Bugis}

Kapal penangkap yang dipergunakan untuk menangkap ikan pelagis kecil di sekitar rumpon adalah kapal kecil. Istilah payang Bugis mulai populer digunakan karena nelayan yang pertama kali menggunakah alat tangkap payang di Pasauran adalah dari suku Bugis (sekitar tahun 1960-an), sehingga sampai sekarang alat ini dinamakan payang Bugis oleh nelayan Pasauran.

Kapal payang Bugis yang ada di lokasi penelitian umumnya berukuran panjang 8$10 \mathrm{~m}$, lebar 2-2.2 m, dan dalam 0.3-0.5 m (sekitar 3 - 3.5 GT). Tenaga pendorong berkekuatan 20 PK sebanyak 1 buah. Dari hasil wawancara, payang Bugis berukuran panjang 65-68 m. Besarnya mata jaring bervariasi dari 1-17 cm. Mata jaring bagian kantung berukuran $1 \mathrm{~cm}$. Spesifikasi satu unit payang Bugis disajikan dalam Tabel 2.

\subsection{Morfologi daun secara visual}

Morfologi daun secara visual pada ketiga atraktor yang berbeda dilakukan pada skala laboratorium dan skala lapangan. Pada skala laboratorium dilakukan perendaman ketiga jenis bahan atraktor. Perendaman ketiga jenis atrak-tor dalam air laut di akuarium untuk melihat dekomposisi daun menunjukkan bahwa daun kelapa relatif lebih awet dibandingkan dengan dua daun lainnya. Di antara daun nipah dan daun pinang, daun nipah lebih awet dari daun pinang. Daun kelapa dan daun nipah menjadi berwarna coklat tua setelah direndam selama 4 minggu (Tabel 3). 
Tabel 2. Spesifikasi Alat Tangkap Jaring Payang Bugis

\begin{tabular}{|c|c|c|c|c|c|c|c|}
\hline \multirow[t]{2}{*}{ Bagian Jaring } & \multirow[t]{2}{*}{ Material } & \multirow{2}{*}{$\begin{array}{l}\text { Besar } \\
\text { Twine }\end{array}$} & \multirow{2}{*}{$\begin{array}{l}\text { Besar mata } \\
(\mathrm{cm})\end{array}$} & \multicolumn{2}{|c|}{ Panjang } & \multicolumn{2}{|c|}{ Lebar } \\
\hline & & & & $\begin{array}{l}\text { Act } \\
(\mathrm{m})\end{array}$ & $\begin{array}{l}\text { Jlh } \\
(\#)\end{array}$ & $\begin{array}{l}\text { Act } \\
(\mathrm{m})\end{array}$ & $\begin{array}{l}\text { Jlh } \\
(\#)\end{array}$ \\
\hline Kantong & $\mathrm{PE}$ & $210 \mathrm{D} \times 6$ & 1 & 2 & 125 & 25.6 & 1600 \\
\hline \multicolumn{8}{|l|}{ Waring } \\
\hline 1 & $\mathrm{PE}$ & $210 \mathrm{D} \times 3$ & 1 & 2 & 125 & 32 & 2000 \\
\hline 2 & $\mathrm{PE}$ & $210 \mathrm{D} \times 3$ & 1 & 2 & 125 & 32 & 2000 \\
\hline 3 & $\mathrm{PE}$ & $210 \mathrm{D} \times 3$ & 1 & 2 & 125 & 32 & 2000 \\
\hline 4 & $\mathrm{PE}$ & $210 \mathrm{D} \times 3$ & 1 & 2 & 125 & 32 & 2000 \\
\hline 5 & $\mathrm{PE}$ & $210 \mathrm{D} \times 3$ & 1 & 2 & 125 & 32 & 2000 \\
\hline Jala kerep & $\mathrm{PE}$ & $210 \mathrm{D} \times 9$ & 7 & 1 & 9 & 166.6 & 1500 \\
\hline Jala arang & $\mathrm{PE}$ & $\begin{array}{lll}210 & D & x \\
10 & & \end{array}$ & 10 & 1 & 9 & 83.3 & 750 \\
\hline Payang sakam & $\mathrm{PE}$ & $210 \mathrm{D} \times 9$ & 25 & 0.5 & 9 & 8.6 & 155 \\
\hline \multicolumn{8}{|l|}{ Sayap } \\
\hline 1 & $\mathrm{PE}$ & $210 \mathrm{D} \times 9$ & 17 & 48 & 900 & 8.3 & 155 \\
\hline 2 & $\mathrm{PE}$ & $210 \mathrm{D} \times 9$ & 17 & 48 & 900 & 8.3 & 155 \\
\hline Selvage 1 & $\mathrm{PE}$ & $210 \mathrm{D} \times 9$ & 17 & 1 & 5 & 3 & 15 \\
\hline Selvage 2 & $\mathrm{PE}$ & $210 \mathrm{D} \times 9$ & 17 & 1 & 5 & 3 & 15 \\
\hline \multicolumn{2}{|l|}{ Bagian Tali } & Material & $\begin{array}{l}\text { Diameter } \\
(\mathrm{mm})\end{array}$ & \multicolumn{2}{|c|}{ Panjang } & \multicolumn{2}{|c|}{ Jumlah } \\
\hline \multirow{3}{*}{\multicolumn{2}{|c|}{$\begin{array}{l}\text { Tali selambar } \\
\text { Tali ris atas } \\
\text { Tali ris bawah }\end{array}$}} & $\mathrm{PE}$ & 10 & \multicolumn{2}{|l|}{50} & \multicolumn{2}{|l|}{2} \\
\hline & & $\mathrm{PE}$ & 8 & \multirow{2}{*}{\multicolumn{2}{|c|}{$\begin{array}{l}50 \\
51\end{array}$}} & \multirow{2}{*}{\multicolumn{2}{|c|}{$\begin{array}{l}2 \\
2\end{array}$}} \\
\hline & & $\mathrm{PE}$ & 8 & & & & \\
\hline
\end{tabular}

Keterangan $: \mathrm{PE}=$ Polyethylene, $\quad$ Act $=$ actual (sebenarnya) $\quad$ Jlh $=$ jumlah mata jaring

Tabel 3. Perubahan fisik tiga jenis bahan atraktor alami dalam percobaan di laboratorium

\begin{tabular}{|c|c|c|c|c|c|c|}
\hline \multirow{2}{*}{$\begin{array}{l}\text { Jenis } \\
\text { daun }\end{array}$} & \multirow{2}{*}{ Indikator } & \multicolumn{5}{|c|}{ Minggu ke } \\
\hline & & 1 & 2 & 3 & 4 & 5 \\
\hline \multirow[t]{4}{*}{ Nipah } & Warna daun & $\begin{array}{l}\text { Hijau } \\
\text { segar }\end{array}$ & Hijau tua & $\begin{array}{l}\text { Hijau } \\
\text { kecoklatan }\end{array}$ & Coklat tua & $\begin{array}{l}\text { Sudah } \\
\text { busuk }\end{array}$ \\
\hline & Warna air & Jernih & Jernih & Jernih & Jernih & Jernih \\
\hline & $\begin{array}{l}\text { Mikroalga } \\
\text { pada daun }\end{array}$ & Tidak ada & Tidak ada & Sedikit & Banyak & Banyak \\
\hline & $\begin{array}{l}\text { Serat-serat } \\
\text { pada daun }\end{array}$ & $\begin{array}{l}\text { Terlihat } \\
\text { jelas }\end{array}$ & Terlihat jelas & $\begin{array}{l}\text { Tidak terlihat } \\
\text { jelas }\end{array}$ & $\begin{array}{l}\text { Tidak terlihat } \\
\text { jelas }\end{array}$ & \begin{tabular}{|l|} 
Tidak \\
terlihat
\end{tabular} \\
\hline \multirow[t]{4}{*}{ Pinang } & Warna daun & $\begin{array}{l}\text { Hijau } \\
\text { segar }\end{array}$ & Hijau tua & $\begin{array}{l}\text { Hijau } \\
\text { kecoklatan }\end{array}$ & $\begin{array}{l}\text { Transparan } \\
\text { (tipis) }\end{array}$ & $\begin{array}{l}\text { Sudah } \\
\text { busuk }\end{array}$ \\
\hline & Warna air & Jernih & Jernih & Jernih & Jernih & Jernih \\
\hline & $\begin{array}{l}\text { Mikroalga } \\
\text { pada daun }\end{array}$ & Tidak ada & Tidak ada & Sedikit & Banyak & Banyak \\
\hline & $\begin{array}{l}\text { Serat-serat } \\
\text { pada daun }\end{array}$ & $\begin{array}{l}\text { Terlihat } \\
\text { jelas }\end{array}$ & $\begin{array}{l}\text { Masih } \\
\text { terlihat jelas }\end{array}$ & $\begin{array}{l}\text { Tidak terlihat } \\
\text { jelas }\end{array}$ & Tidak terlihat & $\begin{array}{l}\text { Tidak } \\
\text { terlihat }\end{array}$ \\
\hline \multirow[t]{4}{*}{ Kelapa } & Warna daun & $\begin{array}{l}\text { Hijau } \\
\text { segar }\end{array}$ & Hijau tua & $\begin{array}{l}\text { Hijau } \\
\text { kecoklatan }\end{array}$ & Coklat tua & $\begin{array}{l}\text { Sudah } \\
\text { busuk }\end{array}$ \\
\hline & Warna air & Jernih & Jernih & Coklat muda & Coklat & Coklat \\
\hline & $\begin{array}{l}\text { Mikroalga } \\
\text { pada daun }\end{array}$ & Tidak ada & Sedikit & Sedikit & Banyak & Banyak \\
\hline & $\begin{array}{l}\text { Serat-serat } \\
\text { pada daun }\end{array}$ & $\begin{array}{l}\text { Terlihat } \\
\text { jelas }\end{array}$ & Terlihat jelas & $\begin{array}{l}\text { Masih terlihat } \\
\text { jelas }\end{array}$ & $\begin{array}{l}\text { Tidak terlihat } \\
\text { jelas }\end{array}$ & $\begin{array}{l}\text { Tidak } \\
\text { terlihat }\end{array}$ \\
\hline
\end{tabular}


Daun atraktor yang sudah dipasang pada suatu perairan memperlihatkan bahwa daun kelapa relatif lebih awet dibandingkan daun pinang dan nipah (Tabel 4). Keadaan daun atraktor rumpon yang dipasang pada suatu perairan pada musim yang berbeda (MP1, MT, MP2, MB) memperlihatkan bahwa urutan ketahanan atraktor daun yang terpasang di perairan dari yang terlama dan terendah adalah daun kelapa, daun nipah dan daun pinang. Rumpon dengan atraktor daun pinang hanya mampu bertahan dalam 15 hari dan akan berwarna bening (transparan) serta tipis, daun nipah akan berwarna coklat kehitaman dalam waktu 19-21 hari, sedangkan daun kelapa akan berwarna coklat kehitaman dalam 24-28 hari.

Tabel 4. Perubahan fisik tiga jenis bahan atraktor alami yang dipasang pada perairan

\begin{tabular}{|c|c|c|c|c|c|}
\hline \multirow{2}{*}{ Jenis daun } & \multirow{2}{*}{ Indikator } & \multicolumn{4}{|c|}{ Minggu ke } \\
\hline & & 1 & 2 & 3 & 4 \\
\hline \multirow[t]{3}{*}{ Nipah } & Warna daun & Hijau segar & Coklat tua & Sudah busuk & \\
\hline & $\begin{array}{l}\text { Alga dan Avert. } \\
\text { pada daun }\end{array}$ & Tidak ada & Banyak & Banyak & \\
\hline & $\begin{array}{l}\text { Serat-serat pada } \\
\text { daun }\end{array}$ & Terlihat jelas & $\begin{array}{l}\text { Masih } \\
\text { terlihat jelas }\end{array}$ & $\begin{array}{l}\text { Tidak terlihat } \\
\text { jelas }\end{array}$ & \\
\hline \multirow[t]{3}{*}{ Pinang } & Warna daun & Hijau segar & $\begin{array}{l}\text { Transparan } \\
\text { atau busuk }\end{array}$ & & \\
\hline & $\begin{array}{l}\text { Alga dan Avert. } \\
\text { pada daun }\end{array}$ & Tidak ada & Sedikit & & \\
\hline & $\begin{array}{l}\text { Serat-serat pada } \\
\text { daun }\end{array}$ & Terlihat jelas & $\begin{array}{l}\text { Tidak terlihat } \\
\text { jelas }\end{array}$ & & \\
\hline \multirow[t]{3}{*}{ Kelapa } & Warna daun & Hijau segar & \begin{tabular}{|l} 
Hijau \\
kecoklatan
\end{tabular} & Coklat tua & $\begin{array}{l}\text { Sudah } \\
\text { busuk }\end{array}$ \\
\hline & $\begin{array}{l}\text { Alga dan Avert. } \\
\text { pada daun }\end{array}$ & Tidak ada & Sedikit & Banyak & Banyak \\
\hline & $\begin{array}{l}\text { Serat-serat pada } \\
\text { daun }\end{array}$ & Terlihat jelas & Terlihat jelas & $\begin{array}{l}\text { Masih terlihat } \\
\text { jelas }\end{array}$ & $\begin{array}{l}\text { Tidak } \\
\text { terlihat jelas }\end{array}$ \\
\hline
\end{tabular}

\subsection{Komposisi hasil tangkapan}

Experimental fishing dengan payang di sekitar rumpon telah berhasil menangkap 17 jenis ikan dan satu jenis binatang lunak (Tabel 5). Sepuluh spesies di antaranya adalah jenis ikan pelagis, yaitu selar hijau (Atule mate), selar kuning (Selaroides leptolepis), kembung lelaki (Rastrelliger kanagurta), selar bentong (Selar crumenophthalmus), layang (Decapterus russelli), sekar taji/layang (Decapterus macrosoma), tongkol (Auxis thazard), tembang (Amblygaster sirm), sunglir (Elagatis bipinnulatus) dan tetengkek
(Megalaspis cordyla). Sisanya adalah ikan demersal, yaitu kuwe (Caranx sexfasciatus), baronang (Siganus guttatus), eteman (Mene maculatus), nomei (Harpodon nehereus), Pomadasys macullatus, Abalistes dan ikan lemuru (Sardinella fimbriata). Binatang lunak yang tertangkap adalah cumi-cumi (Loligo sp.). Komposisi hasil tangkapan dan frekuensi relatif untuk sepuluh spesies ikan pelagis per masing-masing atraktor per musim dapat dilihat pada Tabel 6 dan Gambar 3. 
Tabel 5. Keberadaan spesies ikan dalam hasil tangkapan payang di sekitar tiga jenis rumpon dengan bahan atraktor berbeda

\begin{tabular}{|c|c|c|c|c|c|}
\hline \multirow[t]{2}{*}{ No } & \multirow{2}{*}{ Jenis Ikan } & \multirow{2}{*}{ Musim } & \multicolumn{3}{|c|}{ Jenis bahan atraktor } \\
\hline & & & Nipah & Pinang & Kelapa \\
\hline \multirow[t]{4}{*}{1} & \multirow{4}{*}{$\begin{array}{l}\text { Selar hijau } \\
\text { (Atule mate) }\end{array}$} & MP1 & $\sqrt{ }$ & $\sqrt{ }$ & $\sqrt{ }$ \\
\hline & & MT & $\sqrt{ }$ & $\sqrt{ }$ & $\sqrt{ }$ \\
\hline & & MP2 & $\sqrt{ }$ & $\sqrt{ }$ & $\sqrt{ }$ \\
\hline & & MB & $\sqrt{ }$ & $\sqrt{ }$ & $\sqrt{ }$ \\
\hline \multirow[t]{4}{*}{2} & \multirow{4}{*}{$\begin{array}{l}\text { Selar kuning } \\
\text { (Selaroides leptolepis) }\end{array}$} & MP1 & $\sqrt{ }$ & $\sqrt{ }$ & $\sqrt{ }$ \\
\hline & & MT & $\sqrt{ }$ & $\sqrt{ }$ & $\sqrt{ }$ \\
\hline & & MP2 & $\sqrt{ }$ & $\sqrt{ }$ & $\sqrt{ }$ \\
\hline & & MB & $\sqrt{ }$ & $\sqrt{ }$ & $\sqrt{ }$ \\
\hline \multirow[t]{4}{*}{3} & \multirow{4}{*}{$\begin{array}{l}\text { Kembung lelaki } \\
\text { (Rastrelliger kanagurta) }\end{array}$} & MP1 & $\sqrt{ }$ & $\sqrt{ }$ & $\sqrt{ }$ \\
\hline & & MT & $\sqrt{ }$ & $\sqrt{ }$ & $\sqrt{ }$ \\
\hline & & MP2 & $\sqrt{ }$ & $\sqrt{ }$ & $\sqrt{ }$ \\
\hline & & MB & - & - & - \\
\hline \multirow[t]{4}{*}{4} & \multirow{4}{*}{$\begin{array}{l}\text { Layang panjang } \\
\text { (Decapterus russelli) }\end{array}$} & MP1 & - & - & - \\
\hline & & MT & $\sqrt{ }$ & $\sqrt{ }$ & $\sqrt{ }$ \\
\hline & & MP2 & $\sqrt{ }$ & $\sqrt{ }$ & $\sqrt{ }$ \\
\hline & & MB & - & - & - \\
\hline \multirow[t]{4}{*}{5} & \multirow{4}{*}{$\begin{array}{l}\text { Layang gilik } \\
\text { (Decapterus macrosoma) }\end{array}$} & MP1 & - & - & - \\
\hline & & MT & - & - & $\sqrt{ }$ \\
\hline & & MP2 & $\sqrt{ }$ & $\sqrt{ }$ & $\sqrt{ }$ \\
\hline & & MB & - & - & - \\
\hline \multirow[t]{4}{*}{6} & \multirow{4}{*}{$\begin{array}{l}\text { Tongkol } \\
\text { (Auxis thazard) }\end{array}$} & MP1 & - & - & - \\
\hline & & MT & $\sqrt{ }$ & $\sqrt{ }$ & $\sqrt{ }$ \\
\hline & & MP2 & $\sqrt{ }$ & $\sqrt{ }$ & $\sqrt{ }$ \\
\hline & & MB & - & - & $\sqrt{ }$ \\
\hline \multirow[t]{4}{*}{7} & & MP1 & $\sqrt{ }$ & $\sqrt{ }$ & $\sqrt{ }$ \\
\hline & (Selar rumenophthalmus) & MT & $\sqrt{ }$ & - & $\sqrt{ }$ \\
\hline & & MP2 & - & - & - \\
\hline & & MB & - & - & - \\
\hline 8 & Tembang & MP1 & - & - & - \\
\hline & (Amblygaster sirm) & MT & $\sqrt{ }$ & $\sqrt{ }$ & $\sqrt{ }$ \\
\hline & & MP2 & - & - & - \\
\hline & & MB & - & - & - \\
\hline 9 & Lemuru & MP1 & - & - & - \\
\hline & (Sardinella fimbriata) & MT & $\sqrt{ }$ & $\sqrt{ }$ & $\sqrt{ }$ \\
\hline & & MP2 & - & - & - \\
\hline & & MB & - & - & - \\
\hline 10 & Kuwe & MP1 & - & - & - \\
\hline & (Caranx sexfasciatus) & MT & $\sqrt{ }$ & $\sqrt{ }$ & $\sqrt{ }$ \\
\hline & & MP2 & - & - & - \\
\hline & & MB & - & - & - \\
\hline 11 & Eteman & MP1 & - & - & - \\
\hline & (Mene maculates) & MT & $\sqrt{ }$ & $\sqrt{ }$ & $\sqrt{ }$ \\
\hline & & MP2 & - & - & - \\
\hline & & MB & - & - & - \\
\hline 12 & Baronang & MP1 & - & - & - \\
\hline & (Siganus guttatus) & MT & $\sqrt{ }$ & $\sqrt{ }$ & $\sqrt{ }$ \\
\hline & & MP2 & - & - & - \\
\hline & & MB & - & - & - \\
\hline 13 & Sunglir & MP1 & - & - & - \\
\hline & (Elegatis bipinnulatus) & MT & - & - & $\sqrt{ }$ \\
\hline & & MP2 & - & - & $\sqrt{ }$ \\
\hline & & MB & - & - & - \\
\hline 14 & Tetengkek & MP1 & - & - & $\sqrt{ }$ \\
\hline & (Megalaspis cordyla) & MT & - & - & $\sqrt{ }$ \\
\hline & & MP2 & - & - & - \\
\hline & & MB & - & - & - \\
\hline
\end{tabular}


Tabel 5. (Lanjutan).

\begin{tabular}{|c|c|c|c|c|c|}
\hline \multirow{2}{*}{ No } & \multirow{2}{*}{ Jenis Ikan } & \multirow{2}{*}{ Musim } & \multicolumn{3}{|c|}{ Jenis bahan atraktor } \\
\hline & & & Nipah & Pinang & Kelapa \\
\hline \multirow[t]{4}{*}{15} & \multirow{4}{*}{$\begin{array}{l}\text { Nomei } \\
\text { (Harpodon nehereus) }\end{array}$} & MP1 & $\sqrt{ }$ & - & - \\
\hline & & $\mathrm{MT}$ & - & - & $\sqrt{ }$ \\
\hline & & MP2 & - & - & - \\
\hline & & MB & - & - & - \\
\hline \multirow[t]{4}{*}{16} & \multirow[t]{4}{*}{ Pomadasys macullatus } & MP1 & $\sqrt{ }$ & - & - \\
\hline & & $\mathrm{MT}$ & - & - & $\sqrt{ }$ \\
\hline & & MP2 & - & - & - \\
\hline & & MB & - & - & - \\
\hline \multirow[t]{4}{*}{17} & \multirow[t]{4}{*}{ Abalistes } & MP1 & $\sqrt{ }$ & - & $\sqrt{ }$ \\
\hline & & MT & - & - & - \\
\hline & & MP2 & - & - & - \\
\hline & & MB & - & - & - \\
\hline \multirow[t]{4}{*}{18} & \multirow[t]{4}{*}{ Cumi-cumi (Loligo sp.) } & MP1 & - & $\sqrt{ }$ & - \\
\hline & & MT & - & - & $\sqrt{ }$ \\
\hline & & MP2 & - & - & - \\
\hline & & $\mathrm{MB}$ & - & - & - \\
\hline
\end{tabular}

Keterangan $: \sqrt{ }$ menunjukkan ikan ada pada waktu dan atraktor tersebut

Tabel 6. Komposisi hasil tangkapan ikan pelagis

\begin{tabular}{|c|c|c|c|c|c|}
\hline \multirow{2}{*}{ Atraktor } & \multicolumn{4}{|c|}{ Hasill tangkapan per musim (ekor) } & \multirow{2}{*}{ Jumlah } \\
\hline & MP1 & MT & MP2 & MB & \\
\hline Nipah & 122 & 166 & 78 & 24 & 390 \\
\hline Pinang & 25 & 57 & 27 & 16 & 125 \\
\hline Kelapa & 165 & 358 & 140 & 34 & 674 \\
\hline Jumlah & 312 & 581 & 245 & 74 & 1212 \\
\hline
\end{tabular}

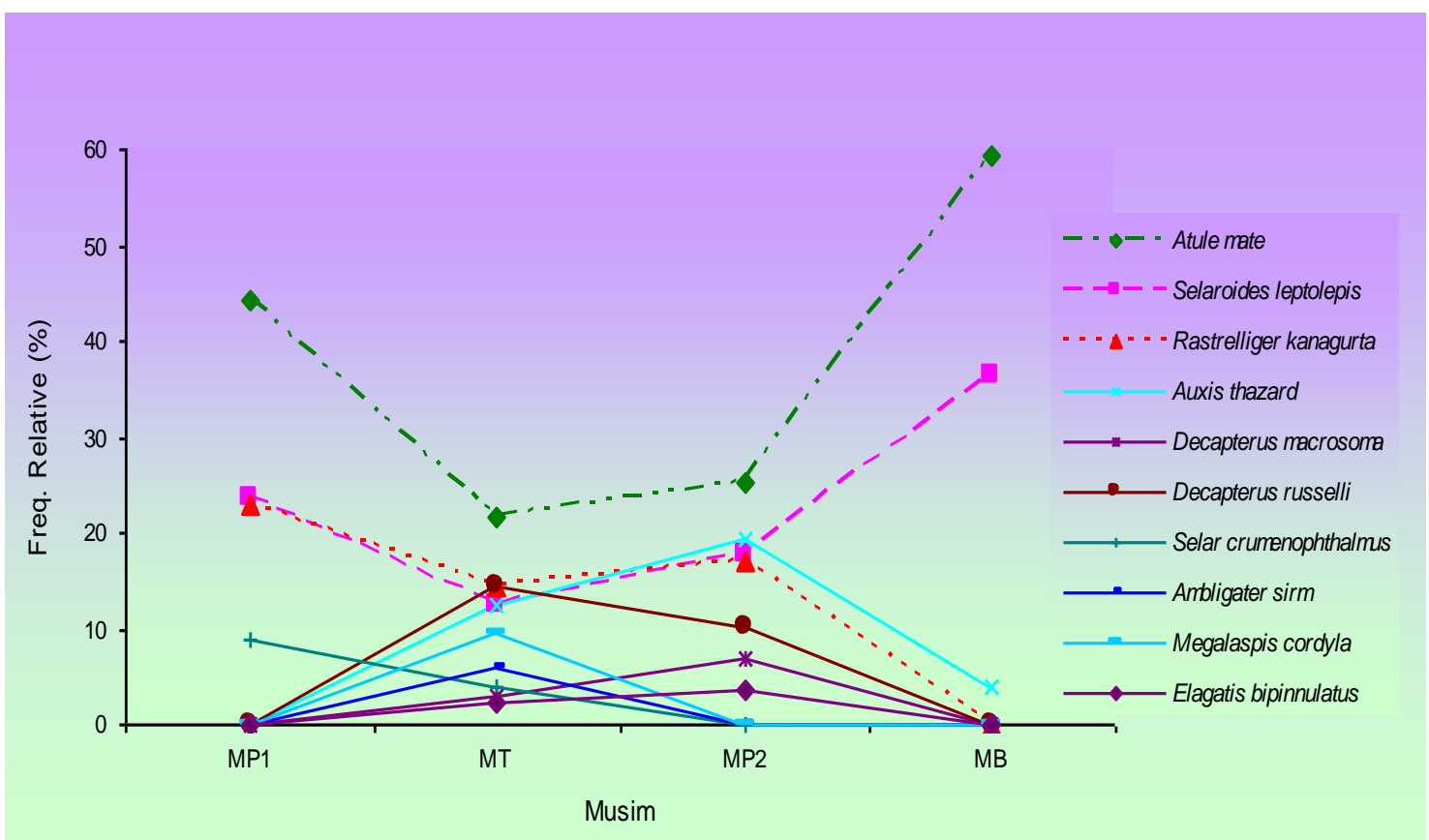

Gambar 3. Frekuensi relatif hasil tangkapan pada ketiga bahan atraktor pada masingmasing musim 
Berdasarkan hasil analisis uji KruskalWallis menunjukkan bahwa hasil tangkapan untuk total hasil tangkapan dari payang sangat signifikan berbeda (P : 0.0; $\mathrm{P}<0.05)$ menurut bahan dan musim. Selanjutnya dari hasil uji jarak berganda Duncan didapatkan bahwa rata-rata hasil tangkapan payang untuk total hasil tangkapan pada bahan rumpon daun kelapa di musim timur paling tinggi (Tabel 7). Berdasarkan jenis bahan rumpon terlihat bahwa ratarata hasil tangkapan pada daun kelapa tidak signifikan berbeda antara musim timur, musim peralihan 1 dan musim peralihan 2, tetapi ketiganya signifikan berbeda lebih tinggi dibandingkan pada musim barat. Pola yang mirip terlihat juga pada bahan rumpon daun nipah dimana hasil tangkapan pada musim peralihan 1 dan musim timur signifikan berbeda lebih tinggi dibanding dengan pada musim barat, sementara pada musim peralihan 2 tidak memperlihatkan perbedaan yang signifikan dengan musim lainnya. Jika dibandingkan dengan kedua bahan lainnya maka daun pinang memberikan respon yang lebih homogen dengan hasil tangkapan yang rendah dan tidak memperlihatkan perbedaan yang signifikan antar musim.

Tabel 7. Hasil analisis Uji jarak Berganda Duncan untuk Hasil Tangkapan Dominan per Bahan Atraktor pada Rumpon per Musim

\begin{tabular}{|c|c|c|c|c|c|c|c|}
\hline \multirow{2}{*}{ Perlakuan } & \multicolumn{6}{|c|}{ Jenis Ikan } & \multirow{2}{*}{ Total } \\
\hline & AT & SL & $\mathbf{A M}$ & RK & SF & DR & \\
\hline 1 & $3.33 \mathrm{bc}$ & $3.11 \mathrm{bc}$ & 6.11 cde & $0.00 \mathrm{a}$ & $3.33 \mathrm{bcd}$ & $0.00 \mathrm{a}$ & $15.89 \mathrm{bc}$ \\
\hline 2 & $0.56^{\mathrm{a}}$ & 0.33 a & $1.44 \mathrm{bc}$ & 0.00 a & $1.11^{\mathrm{a}}$ & $0.00^{a}$ & $3.44^{\mathrm{a}}$ \\
\hline 3 & $4.11^{c}$ & $4.78 \mathrm{~cd}$ & $7.78 \mathrm{de}$ & $0.00^{a}$ & $4.11 \mathrm{~cd}$ & $0.00^{a}$ & $20.78^{c}$ \\
\hline 4 & $2.56 \mathrm{bc}$ & $2.56 \mathrm{bc}$ & $4.00 \mathrm{bcd}$ & $2.78^{c}$ & $2.33 \mathrm{abc}$ & $3.67 \mathrm{c}$ & $17.89 \mathrm{bc}$ \\
\hline 5 & $0.56^{a}$ & 0.33 a & $1.78 \mathrm{ab}$ & $1.00 \mathrm{ab}$ & $1.33 \mathrm{ab}$ & $1.11^{\mathrm{ab}}$ & $6.11^{a}$ \\
\hline 6 & $5.00^{c}$ & $5.22 \mathrm{~d}$ & $8.22 \mathrm{e}$ & $5.44 \mathrm{~d}$ & $5.67 \mathrm{~d}$ & $6.33 \mathrm{~d}$ & $35.89 \mathrm{~d}$ \\
\hline 7 & $1.56 \mathrm{ab}$ & $1.56 \mathrm{ab}$ & $2.22 \mathrm{ab}$ & $1.56 \mathrm{bc}$ & $0.44^{a}$ & $1.78 \mathrm{bc}$ & $9.11 \mathrm{ab}$ \\
\hline 8 & $0.56^{\text {a }}$ & $0.33^{\text {a }}$ & $1.00^{\mathrm{a}}$ & $0.56 \mathrm{ab}$ & $0.44^{\mathrm{a}}$ & 0.56 a & $3.44^{\mathrm{a}}$ \\
\hline 9 & $3.11 \mathrm{bc}$ & $2.89 \mathrm{bc}$ & $3.67 \mathrm{abcd}$ & $2.56^{c}$ & $1.89 \mathrm{abc}$ & $2.33^{c}$ & $16.44 \mathrm{bc}$ \\
\hline 10 & 0.00 a & $1.00 \mathrm{ab}$ & $3.00 \mathrm{abc}$ & 0.00 a & $1.17 \mathrm{ab}$ & 0.00 a & $5.17 \mathrm{a}$ \\
\hline 11 & 0.00 a & $1.00 \mathrm{ab}$ & $1.67 \mathrm{ab}$ & 0.00 a & 0.33 a & 0.00 a & 3.00 a \\
\hline 12 & $0.50 \mathrm{a}$ & $2.50 \mathrm{bc}$ & $2.67 \mathrm{ab}$ & $0.00^{a}$ & $2.17 \mathrm{abc}$ & $0.00^{a}$ & $7.83 \mathrm{ab}$ \\
\hline
\end{tabular}

Keterangan :

ab, bc, cd, abc, bcd, cde, abcd pada kolom yang sama menunjukkan hasil yang berbeda nyata AT Auxis thazard

SL Selaroides leptolepis

AM Atule mate

RK Rastrelliger kanagurta

DR Decapterus russelli

1. Hasil tangkapan pada nipah pada MP1

2. Hasil tangkapan pada pinang pada MP1

3. Hasil tangkapan pada kelapa pada MP1

4. Hasil tangkapan pada nipah pada MT

5. Hasil tangkapan pada pinang pada MT

6 Hasil tangkapan pada kelapa pada MT

Ikan pelagis yang tertangkap adalah selar hijau (Atule mate), selar kuning (Selaroides leptolepis), kembung lelaki (Rastrelliger kanagurta), tongkol (Auxis thazard), ikan layang gilik (Decapterus macrosoma), selar bentong (Selar crumenopthalmus), tembang (Amblygaster sirm), tetengkek (Megalaspis cordyla) dan ikan sunglir (Elegatis bipinnulatus). Tertangkapnya ikan pelagis kecil di sekitar rumpon adalah wajar karena ikan pelagis kecil umumnya berada di lapisan air paling atas.
7. Hasil tangkapan pada nipah pada MP2

8. Hasil tangkapan pada pinang pada MP2

9. Hasil tangkapan pada kelapa pada MP2

10.Hasil tangkapan pada nipah pada MB

11.Hasil tangkapan pada pinang pada MB

12. Hasil tangkapan pada kelapa pada MB

Oleh karena itu bahan atraktor rumpon biasanya dikonsentrasikan untuk di pasang di bagian atas.

Dalam penelitian ini diperoleh juga ikan beronang (Siganus guttatus) yang cukup besar pada musim Timur. Tertangkapnya ikan demersal yang biasanya berasosiasi dengan rumput laut ini kemungkinan disebabkan oleh jarak antara tempat pemasangan rumpon dengan gosong atau terumbu karang yang sudah mati dan padang lamun di pantai terdekat. 
Penelitian yang dilakukan pada musim peralihan 1 pada bulan Maret, musim timur pada bulan Juni, musim peralihan 2 pada bulan September dan musim barat pada bulan Desember menunjukkan bahwa ikan yang selalu tertangkap dengan menggunakan payang adalah ikan selar hijau (Atule mate) dan selar kuning (Selaroides leptolepis). Hal ini sesuai dengan data statistik perikanan setempat dan hasil penelitian Monintja (2003) yang menunjukkan bahwa ikan yang selalu tertangkap sepanjang tahun oleh payang Bugis dan pancing kotrek adalah selar hijau (Atule mate), selar kuning (Selaroides leptolepis) dan selar bentong (Selar crumenopthalmus). Sedang-kan ikan yang menetap secara sementara adalah ikan kembung lelaki (Rastrelliger kanagurta), tongkol (Auxis thazard), ikan layang gilik (Decapterus macrosoma), layang panjang (Decapterus russelli) dan tembang (Amblygaster sirm). Hal ini juga sesuai dengan sifat ikan famili carangidae yang pada umumnya hidup di perairan paparan benua (continental shelf), sedangkan sebagian ikan-ikan scombridae umumnya bersifat neritik dan sebagian lagi bersifat oseanik.

Ukuran ikan terkecil yang tertangkap di sekitar rumpon didapatkan pada musim peralihan 1 dengan ukuran $5.3 \mathrm{~cm}$ dan berat 9.8 gr terdapat pada ikan selar hijau (Atule mate). Ukuran ikan terbesar yang tertangkap di sekitar rumpon didapatkan pada musim timur dengan ukuran $28.0 \mathrm{~cm}$ dan berat 356.5 gr terdapat pada ikan tongkol (Auxis thazard). Secara umum, pada masing-masing ukuran ikan yang tertangkap adalah kecil dan relatif pendek. Berdasarkan length at first maturity, ikanikan tersebut umumnya tertangkap dalam keadaan belum memijah. Ikan-ikan yang tertangkap pada ketiga rumpon dan pada seluruh musim memiliki gonad dengan status TKG I, II dan III secara berturut-turut adalah 4\%, 33\% dan 35\%. Ikan dengan status TKG IV dan V secara berturut-turut adalah 25\% dan 3\%. Dengan demikian dapat dipastikan bahwa ikan-ikan yang berkumpul dan tertangkap di sekitar rumpon adalah ikan yang belum memijah atau belum dewasa sehingga akan membahayakan kelestarian sumberdaya perikanan di perairan Pasauran.

Hasil penelitian ini menunjukkan bahwa $72.1 \%$ tertangkap individu ikan-ikan di sekitar rumpon berstatus TKG I-III atau berukuran kurang dari length at first maturity. Sedangkan individu ikan yang ber- status TKG IV dan V adalah $24.8 \%$ dan $3.1 \%$. Pemanfaatan rumpon laut dangkal sebagai salah satu alat bantu dalam penangkapan ikan pelagis dikhawatirkan akan berdampak negatif terhadap kelestarian sumberdaya ikan di perairan sekitar Pasauran. Kekhawatiran bagi sumberdaya perikanan di perairan Pasauran cukup beralasan, mengingat pengelolaan yang bertujuan untuk pelestarian sumberdaya bagi kegiatan perikanan tangkap masih kurang efektif. Hal ini berarti sifat open access tersebut perlu direvisi dalam konteks pengendalian upaya penangkapan ikan. Hal ini juga berkaitan erat dengan isu internasional yang berkembang sejak Konferensi Internasional tentang Fish Aggregating Device di Martinique, Perancis pada tahun 1999. Tentu saja isu ini berdasarkan pada Code of Conduct for Responsible Fisheries yang dikeluarkan oleh FAO pada tahun 1995. Isu internasional yang ada adalah bahwa FAD sebagai alat bantu dalam penangkapan ikan mengancam kelestarian sumberdaya ikan di perairan. Hal ini dikarenakan alat tangkap purse seine yang berkembang dengan pesat di Samudera Pasifik pada drifting fish aggregating device menangkap ikan-ikan tuna berukuran kecil yang belum matang gonad. Terdapat pro dan kontra tentang hal itu karena FAD merupakan alat bantu yang diyakini sangat efektif dalam menangkap ikan dengan menggunakan alat tangkap purse seine. Purse seine merupakan alat tangkap yang efektif untuk menangkap ikan di sekitar FAD, hanya trawl yang bisa dijadikan alat tangkap pembanding dalam keefektifannya menangkap ikan.

Mengingat bahwa rumpon merupakan alat bantu yang efektif dalam mengumpulkan dan menangkap ikan-ikan yang berukuran kecil dan belum matang gonad, maka diperlukan penerapan pengelolaan yang bersifat konservatif dan cautionary (berhati-hati). Alternatif solusi pengelolaan yang ditawarkan adalah pengelolaan secara berkelompok diantara sesama nelayan pemilik rumpon (community based management); pengendalian terhadap jumlah upaya penangkapan ikan, khususnya jumlah armada penangkap ikan; pengaturan jumlah dan jarak rumpon; penghentian rumpon yang telah mengalami kerusakan bagi rumpon yang sudah ada serta penghentian penambahan rumpon. 


\subsection{Tingkat Kematangan Gonad}

(1) Musim Peralihan 1

Dari 312 individu ikan yang terdiri dari 10 spesies ikan yang tertangkap di sekitar rumpon dengan menggunakan payang, 5 spesies ikan tertangkap mulai dari individu yang memiliki gonad dengan TKG I. Tiga dari sepuluh spesies tersebut berhasil tertangkap individu ikan dengan TKG V, yaitu selar hijau, selar kuning dan kembung lelaki. Komposisi ikan TKG I, II dan III secara berturut-turut adalah $4.2 \%$; $26.6 \%$ dan $39.4 \%$.

(2) Musim Timur

Dari 581 individu ikan yang terdiri dari 10 spesies ikan yang tertangkap di sekitar rumpon dengan menggunakan payang, hanya 1 spesies ikan tertangkap dengan tidak memiliki gonad dengan TKG I yaitu ikan selar kuning. Tiga dari sepuluh spesies tersebut tidak berhasil tertangkap individu ikan dengan TKG V, yaitu layang gilik, selar bentong dan sunglir. Komposisi ikan TKG I, II dan III secara berturut-turut adalah $3.7 \% ; 37.2 \%$ dan $32.6 \%$.

(3) Musim Peralihan 2

Dari 245 individu ikan yang terdiri dari 10 spesies ikan yang tertangkap di se- kitar rumpon dengan menggunakan payang, 3 spesies ikan tertangkap dengan tidak memiliki gonad dengan TKG I, yaitu ikan selar bentong, tembang dan baronang. Empat dari sepuluh spesies tersebut berhasil tertangkap individu ikan dengan TKG V, yaitu selar hijau, selar kuning, kembung lelaki dan tongkol. Komposisi ikan TKG I, II dan III secara berturut-turut adalah $4.7 \%$; $35.2 \%$ dan $33.1 \%$.

\section{(4) Musim Barat}

Dari 74 individu ikan yang terdiri dari 10 spesies ikan yang tertangkap di sekitar rumpon dengan menggunakan payang, satu spesies ikan tertangkap mulai dari individu yang memiliki gonad dengan TKG I yaitu selar hijau. Dua dari sepuluh spesies tersebut berhasil tertangkap individu ikan dengan TKG V, yaitu selar hijau dan selar kuning. Komposisi ikan TKG I, II dan III secara berturut-turut adalah $1.4 \% ; 23.0 \%$ dan $41.9 \%$.

Secara umum, ikan-ikan hasil tangkapan memiliki gonad dengan status TKG I, II dan III secara berturut-turut adalah $4 \%$, 33\% dan 35\% (Gambar 4). Sedangkan ikan yang tertangkap dengan TKG IV dan V berturut-turut adalah 25\% dan 3\%.

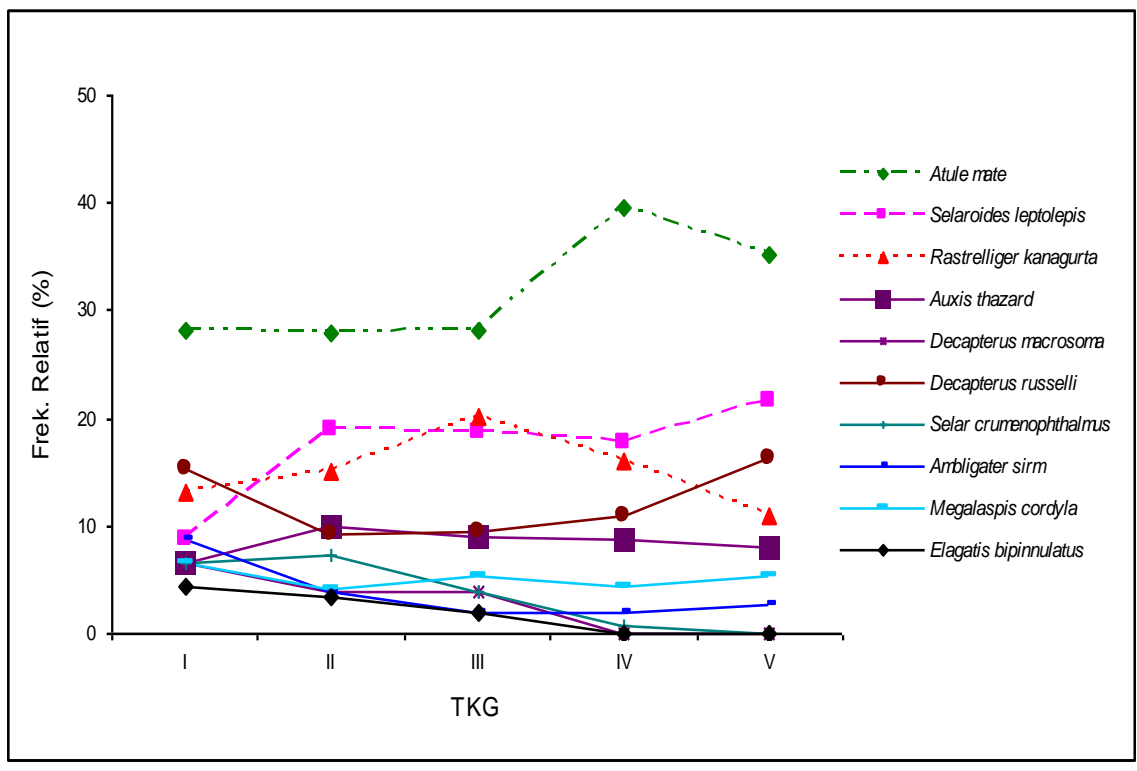

Gambar 4. Tingkat Kematangan Gonad Total Ikan Hasil Tangkapan 


\section{KESIMPULAN DAN SARAN}

\subsection{Kesimpulan}

(1) Jumlah dan keragaman spesies ikan terbanyak pada musim yang berbeda di peroleh dari penangkapan ikan di dekat rumpon yang memiliki atraktor dari daun kelapa. Sedangkan jumlah dan keragaman spesies ikan terendah di peroleh dari penangkapan ikan di dekat rumpon yang memiliki atraktor dari daun pinang.

(2) Ikan-ikan yang tertangkap pada rumpon memiliki gonad dengan status TKG I, II dan III secara berturut-turut adalah 4\%, 33\% dan 35\%. Dengan demikian dapat dipastikan bahwa ikan-ikan yang berkumpul dan tertangkap di sekitar rumpon adalah ikan yang belum memijah atau belum dewasa, sehingga ikan tersebut tidak sempat melakukan reproduksi. Penangkapan ikan yang gonadnya masih berstatus TKG I, II dan III mungkin dapat menyebabkan recruitment overfishing.

\subsection{Saran}

(1) Diperlukan penelitian lebih lanjut mengenai besarnya upaya penangkapan pada rumpon laut dangkal dengan menggunakan payang Bugis yang disesuaikan dengan jumlah rumpon yang optimum untuk menghindari upaya penangkapan yang berlebih.

(2) Perlu penerapan closed dan open season area di perairan Pasauran yang disesuaikan dengan penentuan waktu penangkapan ikan untuk menghindari banyak tertangkapnya individu ikan yang belum layak untuk ditangkap.

\section{DAFTAR PUSTAKA}

A.P.H.A., $1989 . \quad$ Standard Methods for Examination of Water and Wastewater. 17 th Edition, Wash-ington DC. P. : 1044-1075.

Barus, H. R., M. Linting, N. Naamin, S. Ilyas, M. Badrudin, C. Nasution, E. M. Amin, B. Gafa dan Sarjana. 1992. Pedoman Teknis Peningkatan Produksi dan Efisiensi melalui Penerapan Teknologi Rumpon. Departemen Pertanian Badan Penelitian dan Pengembangan Pertanian, Pusat Penelitian dan Pengembangan Perikanan. Jakarta. 87 hal.
Castro, J. J., Jose A. S., and A. T. S. Ortega. 2002. A general Theory on Fish Aggregation to Floating Objects : An Alternative to the Meeting Point Hypothesis. Fish Biology and Fisheries, $11: 255-277$.

Cotel, P. and D. Petit. 1996. Target Strength Measurements on Three Pelagic Fishes from the Java Sea. Fourth Asian Fisheries Forum, 16-20 October 1995, Beijing. P. 109-117.

Dagorn, L., Kosse, E., Bach, P. and Bertrand, A. 2000. Modelling Tuna Behaviour near Floating Objects : from Individuals to Aggregations. Aquatic Living Res-ources. 13 : 203211.

Dinas Perikanan Dati II Kabupaten Serang. 1999. Monografi Perikanan Kabupaten Pandeglang (tidak dipublikasikan).

Direktorat Jenderal Perikanan. 1995. Penggunaan payaos/rumpon di Indonesia. Jakarta. 11 hal.

Effendie, M. I. 1979. Metode Biologi Perikanan. Yayasan Dewi Sri. Bogor. Hal. 15-85.

FAO. 1995. Code of Conduct for Responsible Fisheries. Rome, Italy. 41 p.

FAO. http://www.fishbase.org.

FAO. 1996. Pedoman Teknis untuk Perikanan Bertanggungjawab. Operasi Penangkapan Ikan. Diterjemahkan oleh Direktorat Jenderal Perikanan bersama Pusat Penelitian dan Pengembangan Perikanan, Badan Penelitian dan Pengembangan Pertanian dan Institut Pertanian Bogor, 1999, Fishing Operations. 115 hal.

Fischer, W. and P. J. P. Whitehead. 1974. FAO Species Identification Sheets for Fishery Purposes. Eastern Indian Ocean (Fishing Area 57) and Western Central Pasific (Fishing Area 71). Vol. II dan III. FAO, Rome.

Freon, P. and L. Dagorn. 2000. Review of Fish Associate Behaviour : Toward a Generalisation of The Meeting Point 
Hypothesis. Fish Biology and Fisheries, $10: 183-207$.

Gooding, R. M. and J. J. Magnuson. 1967. Ecological Significance of A drifting Object to Pelagic Fishes. Pasific Science, 21 : 486-497.

Grofit, E. 1980. The Fishing Technology Unit (FTU). FAO Fisheries Technical Papers. FAO. Rome. $48 \mathrm{p}$.

MacLennan, D. N. and E. John Simmonds. 1992. Fisheries Acoustics. Chapman and Hall. London-New YorkTokyo-Melbourne-Madras. $325 \mathrm{p}$.

Mardiana, N. 1999. Prosedur Analisis Tanaman. Unit Penelitian Bioteknologi Tanaman. UPT Bioteknologi, Bogor. 24 hal.

Merta, I.G.S., S. Nurhakim dan J. Widodo. 1998. Sumberdaya perikanan pelagis kecil. dalam potensi dan penyebaran sumberdaya ikan laut di perairan Indonesia. Komisi Nasional Pengkajian Stok Sumberdaya Ikan Laut, Jakarta. Hal 89-106.

Mitson, R. B. 1983. Fisheries Sonar. Fishing News Books Ltd. Farnham, Surrey, England. 287 p.

Monintja, D. R. 1993. Study on the Development of Rumpon as Fish Aggregating Devices (FADs). Maritek, Bulletin ITK, FPIK-IPB. 3(2) : 137 p.

Monintja, D. R., J. Widodo dan F. A. Sondita. 2003. engkajian Terhadap Pemanfaatan Rumpon untuk Penangkapan Ikan Pelagis: Antisipasi Terhadap Implementasi Code of Conduct for Responsible Fisheries. Laporan Riset Unggulan Terpadu VIII. Kementrian Riset dan Teknologi Republik Indonesia, Lembaga Ilmu Pengetahuan Indonesia, Jakarta. 96 hal. (Tidak dipublikasikan).
Nasoetion, A. H., dan Barizi. 1980. Metode Statistika untuk Menarik Kesimpulan. PT. Gramedia. Jakarta. 223 hal.

Steel, R.G.D. and Torrie, J.H., 1989. Prinsip dan Prosedure Statistika (suatu pendekatan biometrik). Alih bahasa B. Sumantry. P.T. Gramedia, Jakarta. 748 p.

Taquet, M., L. Reynal and M. Laurans. 1999. Do FADs Influence The Geographical Distribution of Dolphinfish (Coryphaena hipporus). Peche Thoniere et Dispositifs de Concentration de Poissons. Caraibe-Martinique, 15-19 October 1999. p. 528-536.

Tim Pengkajian Rumpon Fakultas Perikanan Institut Pertanian Bogor. 1987. Laporan Akhir Survai Lokasi dan Desain Rumpon di Perairan Ternate, Tidore, Bacan dan sekitarnya. Laporan. Jurusan Pemanfaatan Sumberdaya Perikanan. Fakultas Perikanan. Institut Pertanian Bogor, Bogor. Hal. V. 54-58 (Tidak dipublikasikan).

Widodo, J. 1997. Review of The Small Pelagic Fisheries in Indonesia. Proceedings Asia Pasific Fisheries Commission Food and Agriculture Organizatiion of The United Nations Office for Asia and the Pasific. Bangkok, Thailand. P. 199-226.

Widodo, J., K. A. Aziz, B. E. Priyono, G. H. Tampubolon, N. Naamin dan A. Djamali (Editor). 1998. Potensi dan Penyebaran Sumber Daya Ikan Laut di Perairan Indonesia. Komisi Nasional Pengkajian Stok Sumber Daya Ikan Laut. Jakarta. 42 hal.

Yamaji, L. 1976. Illustration of Marine Plankton of Japan. Hoikusha Publishing Co. Ltd, Japan. 360 p. 